\title{
RECIPE TO INCREASE REPURCHASE INTENTION FOR AIRLINES IN INDONESIA
}

\author{
Ronald $^{1}$, Amelia $^{2}$ \\ Universitas Pelita Harapan, Surabaya Campus \\ ${ }^{1}$ ronald.suryaputra@uph.edu \\ 2amelia.fe@uph.edu
}

\begin{abstract}
The increase in population indirectly has a positive impact on air transport passengers, significantly affecting the aviation industry. In order to win the competition, Lion Air should focus on customer loyalty. Moreover, Lion Air itself is a multinational airline. This study will focus on examining the effect of service quality, product quality, price to customer loyalty through customer satisfaction. This type of research is causal research because this study is used to explain the causal relationship between variables in the research model. The sampling method used in this research is non-probability sampling. The sample used in this study was 200 respondents of Lion Air passenger in Surabaya. The result of this research finds that from four hypotheses, all hypotheses are accepted. It is found that service quality, product quality and price influence significantly to customer satisfaction. Then, customer satisfaction influence significantly to customer loyalty.
\end{abstract}

Keyword: service quality, product quality, price, customer satisfaction, customer loyalty

\section{INTRODUCTION}

In Indonesia, there are many types of transportation that can be used as the movement of people and goods from one place to another in order to make it easier for everyone to carry out activities every day. The contribution of air transportation not only makes it easier for people to travel in domestic areas, but in the tourism sector also aims to provide international air transport services with the aim of bringing as many tourists as possible to Indonesia in order to increase the country's foreign exchange income.

The increase in population indirectly has a positive impact on air transport passengers, significantly affecting the aviation industry. By removing some of the usual passenger services, the concept of Low Cost Carriers was born.In Indonesia itself, the initial development of the LCC was aimed at creating a market that was affordable to all levels of society by providing routes where the market was not yet potential. In order not to suffer losses, the LCC must regulate its business by adjusting all operational costs to be low cost, of course without neglecting the security, facilities, safety and aviation services. Some costs that are difficult to reduce because the nature of the charges is the same for each operator, namely aviation fuel, airport fees, tax burdens and travel insurance.

One of the LCC airlines in Indonesia that has the largest market share is Lion Air, where Lion Air itself is also a multinational airline, which serves flights from Indonesia to Singapore, the Philippines, Malaysia, Thailand, Australia, India, Hong Kong and other countries. Lion Air itself also has a long history, starting in 1999 when it was founded by Rusdi and Kusnan Kirana, where 
Lion Air has grown so rapidly that it is now able to dominate the market share of LCC flights in Indonesia.

Lion Air itself is also part of the International Air Transport Association which is the second member after Garuda Indonesia, where Lion Air mostly uses Boeing 737 series aircraft. In 2018, Lion Air received an award as the airline with the best marketing strategy in Southeast Asia where the assessment was given by Markplus. This is in line with the rapid growth of Lion Air's airline business with a flight frequency of up to 1500 flights per day. Lion Air also has the strength to serve various routes to small cities in Indonesia. This achievement shows Lion Air's good ability to maintain and increase customer loyalty.

In marketing Lion Air's airline services, Lion Air must prioritize several important things, namely: service quality, product quality, price in using services, customer satisfaction and of course very influential on customer loyalty (Lenka et al, 2009). In terms of service quality, Lion Air provides ticket booking services through a website or application on your cellphone. Lion Air is equipped with technological advancements that allow Lion Air to excel in terms of innovations made to help consumers get closer to Lion Air quickly, easily, anywhere and anytime. In this case, the product quality of Lion Air is quite high. For example, Lion Air sells several products that use the Lion Air logo itself, such as clothes, where the materials used are materials that are not easily damaged.

The price given by Lion Air is definitely different from other airlines. Lion Air uses the concept of Low Cost Carriers, where Lion Air eliminates costs that do not allow customers to use it, such as baggage fees, food and beverage purchases. Lion Air's customer satisfaction can be high or low depending on the product quality, service quality and price felt by consumers. This shows the importance of increasing these three variables in increasing customer loyalty. Satisfied customers will surely be loyal to continue using Lion Air again as the airline to travel.

\section{LITERATURE REVIEW}

\subsubsection{SERVICE QUALITY}

Zeithaml (2006) argues that service quality is a critical element of the customer's perception of the service product it receives. Especially in a product that is purely a service, service quality will be a dominant element in customer assessment. Prentice, et al (2013) suggest that service quality has a direct impact or effect on customer satisfaction. Gruen, et al (2000) stated that service quality is something that causes customer satisfaction to arise. Therefore the hypothesis in this study is H1: Service Quality has a significant influence on Customer Satisfaction.

\subsubsection{PRODUCT QUALITY}

According to Kotler (2005) product quality is the overall characteristics of a product or service on the ability to satisfy stated / implied needs, while according to Lupiyoadi (2001) states that "Consumers will be satisfied if their evaluation results show that the products they use are of high quality. . The relationship between product quality and customer satisfaction is also emphasized by Chase and Qguilano (1995) in Pramita (2010) who argue that the quality of a product is determined 
by customers through the characteristics that exist in a product and service, where customer satisfaction or failure is influenced by value. obtained by consuming a product. The higher the level of product quality in satisfying customers, the higher the customer satisfaction will be (Kotler and Amstrong, 2008). Therefore the hypothesis in this study is

H2: Product Quality has a significant influence on Customer Satisfaction.

\subsubsection{PRICE}

Doyle and Saunders (1985) found empirical evidence that reducing the price will increase the threat when the price will be increased. Another factor that shows that consumers also consider past prices and the form of expectations on future prices that may not be optimal, if consumers delay purchases in anticipation of lower prices in the future. Harjanto (2010) and Ardhana (2010) which show that price has a significant positive effect on customer satisfaction. From this description, it can be seen that purchasing decisions by consumers are influenced by products, one of which is quality, so that it can be made into a hypothesis:

H3: Price has a significant influence on Customer Satisfaction.

\subsubsection{CUSTOMER SATISFACTION}

The overall satisfaction of each satisfaction is an aggregation of all specific evaluations in previous transactions and is updated after each detailed transaction (Jones and Suh, 2000). The satisfaction construct in loyalty research is conceptualized as cumulative satisfaction, rather than an assessment of transaction-specific satisfaction (Harris and Goode, 2004). . Kotler (2000) states that satisfaction is the feeling of a person happy or disappointed resulting from comparing the perceived performance of a product (or results) in relation to its expectations. Sembiring, et al., (2014) stated that customer satisfaction will have a high level of loyalty. on the products or services offered compared to customers who are less or not satisfied, in the sense that Customer Satisfaction is significant towards Customer Loyalty.

H4: Customer Satisfaction has a significant influence on Customer Loyalty.

\subsubsection{CUSTOMER LOYALTY}

According to Griffiin (2005) loyalty is more aimed at non-random behavior shown by routine purchases. Non-random behavior or events, that is, if the customer knows the benefits of certain goods or services and is in accordance with the requirements, the customer tends to be loyal (Griffin, 1995). Oliver (1997) divides the level of loyalty based on the quality and quantity of repurchases and the strength of resistance from competitors' products or services. Customer Loyalty is very important for companies that maintain their business continuity and the continuity of their business activities.

\subsection{THEORITICAL FRAMEWORK}


Theoritical framework in this research is as follow:

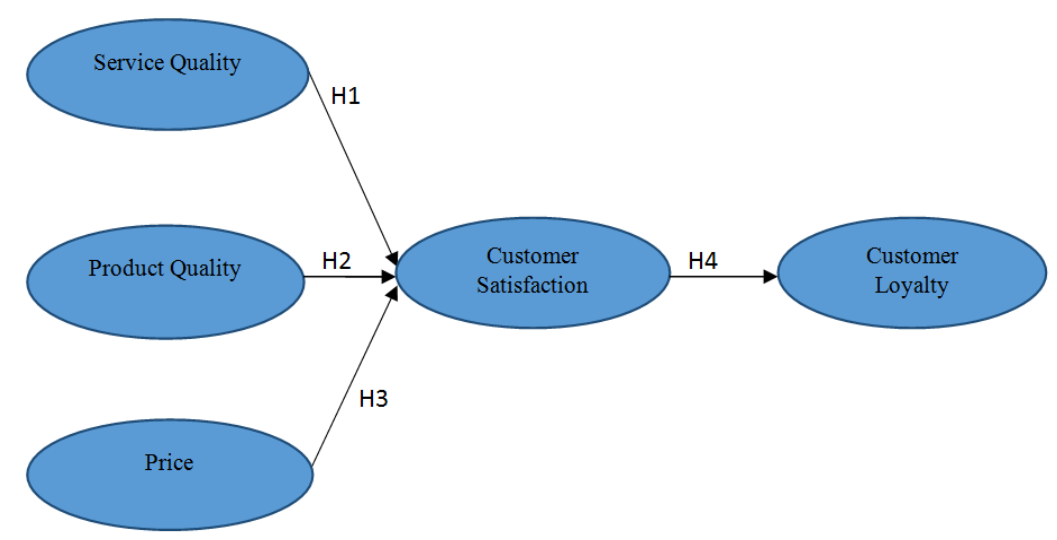

Source: previous journal, 2021

\section{RESEARCH METHODS}

\subsection{RESEARCH SAMPLES}

The sampling technique used is non-probability sampling where questionnaires are the main means of collecting data. According to Hair et al. (2007), researchers generally will not analyze a sample of less than 50 samples. The sample size as a general rule should be 100 samples or larger. The minimum sample size is five observations for each parameter estimated. The number of samples used in this study were 200 Lion Air customers in Surabaya.

\subsection{ANALYSIS METHOD}

The data processing model used to analyze the data is simple regression (simple regression) and multiple linear regression (multiple regression) from the software package SPSS 16.0. The model and hypothesis testing in this study were first analyzed with a simple regression technique which allowed the researcher to test directly the effects of the intervening variables on the related variables and also directly test the effect of the independent variable on the dependent variable which was built from several indicators.

\section{RESULTS}

\subsection{Findings}

This study used Multiple Regression in testing between the variables. Statistical analysis tool used to answer the problem formulation of this research is SPSS 22.0. Once the questionnaires were returned, the next step that must be conducted is descriptive statistic-analysis. In Table 1, it shows that respondents who fill out questionnaires are mostly done by men, this can be seen from 107 respondents $(53,5 \%)$ of respondents who fly with Lion Air while 93 respondents $(46,5 \%)$ are women. This indicates that customer of Lion Air mostly is men. 


\begin{tabular}{|l|l|r|r|r|r|}
\hline \multicolumn{2}{|l|}{ Table 1.Respondents Characteristic by Gender } \\
\hline \multicolumn{7}{|c|}{} & Frequency & \multicolumn{1}{l|}{ Percent } & Valid Percent & $\begin{array}{l}\text { Cumulative } \\
\text { Percent }\end{array}$ \\
\hline \multirow{3}{*}{ Valid } & Female & 107 & 53.5 & 53.5 & 53.5 \\
\cline { 2 - 6 } & Male & 93 & 46.5 & 46.5 & 100.0 \\
\cline { 2 - 6 } & Total & 200 & 100.0 & 100.0 & \\
\hline
\end{tabular}

From the results in Table 2, it can be seen that the characteristics of respondents based on age are dominated by age group 18-35 which is 156 respondents (78\%), followed by $36-50$ age group which is 38 respondents $(19 \%)$, and last age group which is become respondents is age group 51-60 which is 6 respondents (3\%). This shows that the majority of respondents are in the age of 18 -35 or we can call it millenials.

Table 2. Respondents Characteristic by Age

\begin{tabular}{|l|l|r|r|r|r|}
\hline \multicolumn{2}{|c|}{} & Frequency & Percent & Valid Percent & \multicolumn{2}{|l|}{$\begin{array}{l}\text { Cumulative } \\
\text { Percent }\end{array}$} \\
\hline \multirow{3}{*}{ Valid } & $18-35$ & 156 & 78.0 & 78.0 & 78.0 \\
\cline { 2 - 6 } & $36-50$ & 38 & 19.0 & 19.0 & 97.0 \\
\cline { 2 - 6 } & $51-60$ & 6 & 3.0 & 3.0 & 100.0 \\
\cline { 2 - 6 } & Total & 200 & 100.0 & 100.0 & \\
\hline
\end{tabular}

Table 3. Descriptive Statistics

\begin{tabular}{|l|r|r|r|}
\hline & N & Mean & Std. Deviation \\
\hline SQ1 & 200 & 4.360 & .6018 \\
\hline SQ2 & 200 & 4.320 & .5911 \\
\hline SQ3 & 200 & 4.360 & .5213 \\
\hline SQ & 200 & 4.455 & .4992 \\
\hline PQ1 & 200 & 4.3738 & .46349 \\
\hline PQ2 & 200 & 4.375 & .5621 \\
\hline PQ3 & 200 & 4.380 & .5542 \\
\hline PQ4 & 200 & 4.360 & .5213 \\
\hline
\end{tabular}




\begin{tabular}{|l|r|r|r|}
\hline PQ & 200 & 4.3875 & .45718 \\
\hline PR1 & 200 & 4.400 & .5671 \\
\hline PR2 & 200 & 4.320 & .5911 \\
\hline PR3 & 200 & 4.380 & .5542 \\
\hline PR4 & 200 & 4.405 & .5121 \\
\hline PR & 200 & 4.3763 & .46754 \\
\hline CS1 & 200 & 4.320 & .5911 \\
\hline CS2 & 200 & 4.380 & .5542 \\
\hline CS3 & 200 & 4.360 & .5213 \\
\hline CS & 200 & 4.3533 & .5107 \\
\hline CL1 & 200 & 4.190 & .5342 \\
\hline CL2 & 200 & 4.305 & .5599 \\
\hline CL3 & 200 & 4.265 & .4646 \\
\hline CL4 & 200 & 4.285 & .4742 \\
\hline CL & 200 & 4.2613 & .45064 \\
\hline Valid N (listwise) & & & \\
\hline Source: own calculation & & & \\
\hline
\end{tabular}

Based on the results from data processing in table 3, it shows that all average score of the mean for overall indicator is above 3.61. This shows that all indicators of variables that tested can be perceived positive by all respondents. In addition, the standard deviation is under 2.0. This shows that the answers given by respondents are homogeneous or relatively the same. It is known that the highest mean average is product quality is 4,3875 . This may indicate that the indicators of product quality is best perceived by the respondents than other variables. Customer satisfaction has the highest score for standard deviation, that is 0,5107 . This may indicate that the respondents give answers for customer satisfaction least homogeneous compared with other variables. Before going for Single Regression and Multiple Regression testing, first steps that must be conducted is the testing of the validity and reliability to prove that the data from the questionnaire is valid, reliable and able to be used for the next analysis.

\subsubsection{Validity Test}

The criteria is if the value of the factor loading is higher than 0.50 , then the statement is considered valid, however, if the value of the factor loading is less than the 0.50 , then the statement is considered invalid or failed. Based on the test of the data validity, it is prove that all indicators used to estimate each variable are valid, since the value of the factor loading for every questions are more than 0.50 .

\begin{tabular}{|c|c|c|c|c|c|c|c|c|c|}
\hline Indicator & FL & Indicator & FL & Indicator & FL & Indicator & FL & Indicator & FL \\
\hline \multicolumn{2}{|c|}{ Service Quality } & \multicolumn{2}{|c|}{ Product Quality } & \multicolumn{2}{|l|}{ Price } & \multicolumn{2}{|c|}{ Customer Satisfaction } & \multicolumn{2}{|c|}{ Customer Loyalty } \\
\hline
\end{tabular}




\begin{tabular}{|c|c|c|c|c|c|c|c|c|c|}
\hline SQ1 & .711 & PQ1 & .612 & PR1 & .526 & CS1 & .811 & CL1 & .819 \\
\hline SQ2 & .767 & $\mathrm{PQ} 2$ & .787 & PR2 & .807 & $\mathrm{CS} 2$ & .843 & CL2 & .763 \\
\hline SQ3 & .642 & $\mathrm{PQ} 3$ & .768 & PR3 & .768 & CS3 & .796 & CL3 & .766 \\
\hline $\mathrm{SQ} 4$ & .684 & $\mathrm{PQ} 4$ & .797 & PR4 & .747 & & & CL4 & .828 \\
\hline
\end{tabular}

\subsubsection{Reliability Test}

Reliability test is do by comparing cronbach's alpha value, if the value is higher than 0.6 , then the statement is considered reliable.

\begin{tabular}{|l|l|}
\hline \multicolumn{2}{|l|}{ Table 5. Reliability Test } \\
\hline Variable & $\begin{array}{l}\text { Cronbach's Alpha Based on } \\
\text { Standardized Items }\end{array}$ \\
\hline service quality & .856 \\
\hline Product quality & .881 \\
\hline price & .862 \\
\hline customer satisfaction & .908 \\
\hline customer loyalty & .909 \\
\hline Source: own calculation & \\
\hline
\end{tabular}

From the table 5, it is proven that the variable of service quality, product quality, price, customer satisfaction and customer loyalty having the Cronbach alpha value higher than 0.60 . So, it can be concluded that the statements develop the variables can be said to be consistent/reliable and can be used for further analysis.

\subsubsection{Results of Multiple Regression}

1. Service Quality, Product Quality, and Price to Customer Satisfaction

The results of multiple regression are as follows:

\begin{tabular}{|c|c|c|c|c|c|c|}
\hline \multicolumn{7}{|c|}{ Table 8. Coefisien Regression Model 1} \\
\hline \multirow{2}{*}{\multicolumn{2}{|c|}{ Model }} & \multicolumn{2}{|c|}{ Unstandardized Coefficients } & \multirow{2}{*}{$\begin{array}{l}\text { Standardized } \\
\text { Coefficients } \\
\text { Beta }\end{array}$} & \multirow[b]{2}{*}{$\mathrm{T}$} & \multirow[b]{2}{*}{ Sig. } \\
\hline & & $\mathrm{B}$ & Std. Error & & & \\
\hline \multirow[t]{5}{*}{1} & (Constant) & -.397 & .106 & & -3.746 & .000 \\
\hline & SQ & .170 & .060 & .154 & 2.832 & .005 \\
\hline & PQ & .460 & .064 & .411 & 7.176 & .000 \\
\hline & PR & .455 & .072 & .417 & 6.317 & .000 \\
\hline & (Constant) & -.397 & .106 & & -3.746 & .000 \\
\hline
\end{tabular}


a. Dependent Variable: CS

Source: own calculation

From table 8, the regression equation can be written as follows:

$$
\begin{aligned}
& \mathrm{CS}=\mathrm{b} 1 \mathrm{SQ}+\mathrm{b}_{2} \mathrm{PQ}+\mathrm{b}_{3} \mathrm{PR} \\
& \mathrm{CS}=.154 \mathrm{SQ}+.411 \mathrm{PQ}+.417 \mathrm{PR}
\end{aligned}
$$

Based on table 8, all the independent variables have positively influence towards customer satisfaction. Product quality has the greatest regression coefficient compare to other variables, that is 0,417 . Therefore, Product quality is the most influence to customer satisfaction. In the other side, service quality has the smallest effect on customer satisfaction, that is service quality

\begin{tabular}{|c|c|c|c|c|c|c|}
\hline \multicolumn{7}{|c|}{ Table 9. Coefisien Regression Model 2} \\
\hline \multirow{2}{*}{\multicolumn{2}{|c|}{ Model }} & \multicolumn{2}{|c|}{ Unstandardized Coefficients } & \multirow{2}{*}{$\begin{array}{l}\text { Standardized } \\
\text { Coefficients } \\
\text { Beta }\end{array}$} & \multirow[b]{2}{*}{$\mathrm{t}$} & \multirow[b]{2}{*}{ Sig. } \\
\hline & & $\mathrm{B}$ & Std. Error & & & \\
\hline \multirow[t]{2}{*}{1} & (Constant) & 1.980 & .221 & & 8.956 & .000 \\
\hline & $\mathrm{CS}$ & .524 & .050 & .594 & 10.388 & .000 \\
\hline \multicolumn{7}{|c|}{ a. Dependent Variable: $\mathrm{CL}$} \\
\hline \multicolumn{7}{|c|}{ Source: own calculation } \\
\hline
\end{tabular}

\section{Customer Satisfaction to Customer Loyalty}

Based on table 9, independent variable have positively influence towards customer loyalty. Customer satisfaction has regression coefficient that is 0,594

From table 9, the regression equation can be written as follows:

$$
\begin{aligned}
& C L=b 4 \mathrm{CS} \\
& \mathrm{CL}=0,594 \mathrm{CS}
\end{aligned}
$$

\subsubsection{Regression t-test}

\section{Service Quality, Product Quality, and Price to Customer Satisfaction}

The t test used to determine whether the independent variables of in Service Quality, Product Quality and Price partially (independently) have significant influence on Customer Satisfaction. If the value of $t$ test is below 0.05 , then it can be stated that the variable is significantly influenced by partially. From table 14, it can be seen that service quality, product quality, and price partially (independently) have significant influence on Customer Satisfaction. 
Table 14. Result of t-test

\begin{tabular}{|c|c|c|c|c|c|c|}
\hline \multirow{2}{*}{\multicolumn{2}{|c|}{ Model }} & \multicolumn{2}{|c|}{ Unstandardized Coefficients } & \multirow{2}{*}{\begin{tabular}{|l|}
$\begin{array}{l}\text { Standardized } \\
\text { Coefficients }\end{array}$ \\
Beta \\
\end{tabular}} & \multirow[b]{2}{*}{$\mathrm{T}$} & \multirow[b]{2}{*}{ Sig. } \\
\hline & & B & Std. Error & & & \\
\hline \multirow[t]{4}{*}{1} & (Constant) & -.397 & .106 & & -3.746 & .000 \\
\hline & SQ & .170 & .060 & .154 & 2.832 & .005 \\
\hline & PQ & .460 & .064 & .411 & 7.176 & .000 \\
\hline & PR & .455 & .072 & .417 & 6.317 & .000 \\
\hline
\end{tabular}

\section{Customer Satisfaction to Customer Loyalty}

The $t$ test used to determine whether the independent variables of Customer Satisfaction partially (independently) have significant influence on Customer Loyalty. If the value of $t$ test is below 0.05 , then it can be stated that the variable is significantly influenced by partially. From table 15, it can be seen that Customer Satisfaction have significant influence on Customer Loyalty.

\begin{tabular}{|c|c|c|c|c|c|c|}
\hline \multicolumn{7}{|c|}{ Table 15. Result of $t$-test } \\
\hline \multirow{2}{*}{\multicolumn{2}{|c|}{ Model }} & \multicolumn{2}{|c|}{ Unstandardized Coefficients } & \multirow{2}{*}{\begin{tabular}{|l|} 
Standardized \\
Coefficients \\
Beta \\
\end{tabular}} & \multirow[b]{2}{*}{$\mathrm{t}$} & \multirow[b]{2}{*}{ Sig. } \\
\hline & & B & Std. Error & & & \\
\hline \multirow[t]{2}{*}{1} & \begin{tabular}{|l} 
(Constant) \\
\end{tabular} & 1.980 & .221 & & 8.956 & .000 \\
\hline & $\mathrm{CS}$ & .524 & .050 & .594 & 10.388 & .000 \\
\hline \multicolumn{7}{|c|}{ a. Dependent Variable: CL } \\
\hline \multicolumn{7}{|c|}{ Source: own calculation } \\
\hline
\end{tabular}

\section{ANALYSIS AND DISCUSSION}

The results of this study shows that the variables service quality, product quality and price have positive and significant effects on customer satisfaction. Also, customer satisfaction have positive and significant effect on customer loyalty. So, the conclusion is that from four proposed hypotheses, all hypotheses are supported.

The first hypothesis stating that service quality has a positive significant effect on customer satisfaction is supported. The first hypothesis stating that service quality has a positive effect on customer satisfaction is supported because the $t$ test value is 0.005 , below 0.05 . This shows the consistency results of this study with Cronin and Taylor (1992) that states that service quality have a significant positive effect on customer satisfaction.

The second hypothesis stating that product quality has a positive significant effect on customer satisfaction is accepted. The second hypothesis stating that product quality has a positive 
effect on customer satisfaction is supported because the $t$ test value is 0.000 below than 0.05 . This shows the consistency results of this study with Qin et al (2010).

The third hypothesis stating that price has a positive significant effect on customer satisfaction is supported. The third hypothesis stating that price has a positive effect on customer satisfaction is supported because the $t$ test value is 0.000 , below 0.05 . This shows the consistency results of this study with Harjanto (2010) that states that price have a significant positive effect on customer satisfaction.

The fourth hypothesis stating that customer satisfaction has a positive significant effect on customer loyalty is supported. The fourth hypothesis stating that customer satisfaction has a positive effect on customer loyalty is supported because the $t$ test value is 0.000 below 0.05 . This shows the consistency results of this study with Sembiring, et al., (2014) that states that customer satisfaction have a significant positive effect on customer loyalty.

\section{CONCLUSION AND RECOMMENDATION}

This model was developed in order to research customer loyalty for Lion Air in Surabaya. This research model formed an influence relationship between service quality, product quality, and price to customer satisfaction. Also, customer satisfaction have positive and significant effect on customer loyalty. So, the conclusion is that from four proposed hypotheses, all hypotheses are supported.

Service quality significantly influences customer satisfaction, which means that the first hypothesis is accepted. This statement is in line with the study conducted by Cronin and Taylor (1992), where service is an important variable to increase customer satisfaction, especially in the airline industry such as Lion Air. So, Lion Air should pay attention more on service quality in the whole value chain of company, start from pre flight, in flight and post flight, the company should pay attention on service quality, even though they set low price.

The analysis result of the research model reveals that product quality significantly influences customer satisfaction, which means that the second hypothesis is accepted. This statement is in line with the study conducted by Qin et al (2010) who say that product quality also has an important influence on consumer satisfaction, because in addition to services, consumers also enjoy the physical form of a product which is sold by Lion Air, such as merchandise.

The analysis result of the research model reveals that price significantly influences customer satisfaction. From the model analysis outcome shows that price has a sigificant influence on customer satisfaction, which means that the third hypothesis is accepted. This statement is in line with the statement stated by Harjanto (2010) who said that one of the important considerations in customer satisfaction is the price specifically for the aviation sector where consumers are quite sensitive to the prices offered by the airline industry players, especially in low cost carrier sector. So, Lion Air should be careful in price setting to make it affordable for the customer.

The analysis result of the research model reveals that customer satisfaction significantly influences customer loyalty. This means that the fourth hypothesis is accepted. This statement is in line with the statement proposed by Sembiring, et al., (2014) where satisfaction is very important for 
consumer loyalty. The requirement for consumers to be loyal is that the consumer must experience satisfaction and then the consumer can become loyal.

\section{References}

Ardhanari, M. (2008). Customer Satisfaction pengaruhnya terhadap brand preference dan repurchase intention private brand. Jurnal Riset Ekonomi dan Bisnis, 60.

Arisman, (2010). Gizi Dalam Daur Kehidupan: Buku Ajar Ilmu Gizi, edisi ke-2. Jakarta: EGC

Akbar, M. M., \& Parvez, N. (2009). Impact of Service Quality, Trust, and Customer Satisfaction on Customer Loyalty. ABAC Journal.

Bagozzi, RP., Gopinath, M., Nyer, P., (1999). The role of emotions in marketing. Journal of the Academy of Marketing Science, 27 (2), 184-206.

Espejel et al. (2008). "Consumer Satisfaction: A key factor of consumer loyalty and buying intention of a PDO food product”, British Food Journal, 110 (9), 865-88

Fang et al. (2011). "Determinants of customer repurchase intention in online shopping,".

Gaspersz, V. (2005). Aplikasi Analisis Multivariate dengan program SPSS. Semarang: Badan Penerbit Universitas di Ponegoro

Hyun, S. S., Kang, J. (2014). A Better Investment In Luxury Restaurants: Environmental or Nonenvironmental cues? International Journal of Hospitality Management, 39, 57-70

Hiller et al. (2003). Repurchase intention: a general structural equation model. Journal of marketing, 37, 1762-180

Irawan, H. (2002). 10 Prinsip Kepuasan Pelanggan. Jakarta: Elex Media Komputindo.

Johns, N., Pine, R., (2002). Customer Behavior in the food service industry: a review, International Journal of Hospitality Management, 21 (2), 119-13

Kotler , \& Armstrong. (2001). Manajemen Pemasaran di Indonesia. Jakarta: Selemba Empat.

Kotler, \& Armstrong. (2010). Principles of Marketing (13rd ed.). New Jersey: Prentice-Hall Inc

Lin, I. Y., (2004). Evaluating a servicescape: the effect of cognition and emotion. International Journal of Hospitality Management, 23, 163-178. 
Law, R., To, T., Goh, C., (2008). Haw do Mainland Chinese travelers choose restaurant in Hong kong? An exploratory study of individual visit scheme travelers and packaged travelers. International Journal of Hospitality Management, 27 (3), 346-354

Mattila, AS., Wirtz, J., (2001). Congruency of scent and music as a driver of in store evaluations and behavior. Journal of Retailing, 77, 273-289.

Martinez, CL., Martinez, G,J,A, (2007). Cognitive-affective model of consumer satisfaction: an exploratory study within the frame work of a sporting event. Journal of Business Research, 60, 108-114.

Morrison, M., Gan, S., Dubelaar, C., Oppewal, H., (2011). In-store music and aroma influences on shopper behavior and satisfaction. Journal of Business Research, 64 (6), 558-564.

Munhurrun, P. R., Bhiwajee, S. D., \& Naidoo, P. (2010). Service Quality In The Public Service. International Journal Of Management And Marketing Research.

Nguyen, N., Leblanc, G., (2002). Contact personnel, physical environment and the perceived corporate image of intangible services by new clients. International Journal of Service Industry Management, 13, $242-262$.

Oliver, R. (1993). Cognitive, effective and attribute \& bases far the satisfaction response. Journal of Consumer Research, 20, 418-430

Qin, H., Prybutok, V. R., \& Zhao, Q. (2010). Perceived service quality in fast food restaurant: Empirical evidence from china. International Journal of Quality \& Reliability Management, 27 (4), 424-437.

Raajpoot, N., (2002). TANGSERV: a multiple item scale for measuring tangible quality in foodservice industry, Journal of Foodservice Business Research, 5, 109-127.

Russell, James A. and Jacalyn Snodgrass (1987), “Emotion and the Environment," in Handbook of Environmental Psychology, Vol. 1, Daniel Stokols and Irwan Altman, eds, New York: John Wiley \& Sons, Inc., 245-281.

Ryu, K., Han., (2010). Influence of the quality of food, service, and physical environment on customer satisfaction and behavioral intention in quick-casual restaurants: moderating role of perceived price. Journal of Hospitality and Tourism Research, 34 (3), 310-329

Shugan, Steven and Jinhong Xie, (2000). "Advance Pricing of Services and Other Implications of Separating Purchase and Consumption," Journal of Service Research, 2, 227-239.

Swastha, B. (2000). Pengantar Bisnis Moderen, Pengantar Ekonomi Perusahaan Moderen, Jakarta: 
Libert

Tjiptono, F. (2006). Manajemen Pelayanan Jasa. Yogyakarta: CV. Andi Offset

Terry, George R. (1988). Principles of Management. Saduran Drs. Sujai. Bandung: Penerbit Grafika.

Widagdo, H. (2009). Analisis pengaruh kualitas layanan dan promosi terhadap keputusan konsumen membeli komputer pada PT. XYZ Palembang. Jurnal Ilmiah STIE MDP, 1.

Yi, Y., La, S., (2004). "What Influences the Relationship between Customer Satisfaction and Repurchase Intention? Investigation the Effects of Adjusted Expectation and Customer Loyalty," Psychology \& Marketing, 21 (5), 351-373.

Zeithaml, V. A., \& Bitner, M. J. (2003). Service Marketing-Integrating Customer Focus Across The Firm ( $3^{\text {rd }}$ ed). New York: Mc Graw Hill Inc. 